Sir John Flett, director of H.M. Geological Survey, for his researches "concerning the mineral structure of the Earth" in the realms of petrological, palæontological and stratigraphical geology ; Murchison Medal to Prof. E. B. Bailey, professor of geology in the University of Glasgow, for his researches in stratigraphical and tectonic geology; Lyell Medal to Prof. D. M. S. Watson, Jodrell professor of zoology and comparative anatomy in University College, London, in recognition that he has "deserved well of the Science" in the fields of palæontological and stratigraphical geology ; Bigsby Medal to Prof. H. H. Read, George Herdman professor of geology in the University of Liverpool, "as an acknowledgement of eminent services" to petrological, structural and stratigraphical geology. The balance of the Wollaston Fund has been awarded to Dr. W. J. Arkell, of the Murchison Fund to Mr. J. V. Harrison, and of the Lyell Fund to Mr. J. J. Hartley and Mr. L. R. Wager.

\section{Edison Medal Award}

THe Edison Medal for 1934 has been awarded by the American Institute of Electrical Engineers to Prof. Willis R. Whitney, "for his contributions to electrical science, his pioneer inventions, and his inspiring leadership in research". The Edison Medal was founded by associates and friends of Thomas A. Edison, and is awarded annually for "meritorious achievement in electrical science, electrical engineering, or the electrical arts" by the American Institute of Electrical Engineers. Prof. Whitney has been vicepresident in general charge of research of the General Electric Company, Schenectady, New York, since 1932.

\section{Equivalence of Energy and Inertial Mass}

ON December 28, during the meeting at Pittsburgh of the American Association for the Advancement of Science, Prof. A. Einstein delivered the Josiah Willard Gibbs Lecture of the American Mathematical Society. The accompanying summary was provided by Prof. Einstein for the use of Science Service : "It is well known that the equivalence between energy and inertial mass is one of the most important consequences of the special theory of relativity; this principle forms at present a useful tool of research in the physics of atomic nuclei. The theoretical derivation of this principle of equivalence, while restricting myself to what is conceptually necessary, is the subject of my lecture. From the Lorentz transformation and the assumption of the impulse and energy principle for material particles, the form of the impulse and energy of the moving particles, as well as the equality of mass and rest-energy, is derived. The whole proof is based on the consideration of an elastic and an inelastic collision between two identically constituted material particles."

\section{Limits of Industrial Employment}

DR. E. C. SNow, in a paper read before the Royal Statistical Society on January 15, discussed "The Limits of Industrial Employment-the Influence of Growth of Population on the Development of Industry". The first part of the paper dealt in con- siderable detail with the facts of growth of population in the nineteenth century and up to the outbreak of War. During a considerable part of that period, the population of England and Wales was increasing at the rate of 300,000-350,000 per annum-entirely due to the decline in the death rate. This decline in mortality was not peculiar to industrialised Great Britain, but was equally marked in other agricultural countries. The analysis of the statistical evidence seems to justify the view that the growth of industry in Great Britain was not the direct cause of the increase in population. The population eircumstances of England and Wales at the present time are widely different from those ruling up to the time of the War. The population at ages under thirty-five years is declining. At ages over sixty it is still increasing, but the net effect is an annual increase of population of not more than a quarter of that before the War. The economic effect of the smaller rate of population growth now is indicated by the fact that the quantity of foodstuffs imported since 1924 has increased at less than 1 per cent per annum. The overseas countries which rely on this market for an outlet for a large part of their production of foodstuffs are living in the expectation that Great Britain can increase its imports of food at the old rate of 5 per cent per annum, whereas, in fact, it has for some time only been increasing at the rate of 1 per cent per annum, and before long even this small rate of increase is likely to decline.

\section{Russian Academy of Sciences}

THe recent decision of the Soviet Government to transfer the Russian Academy of Sciences and its affiliated institutions from Leningrad to Moscow marks the beginning of a new period in the history of the Academy, which dates back more than two hundred years. As is pointed out in the Izvestia, the transference is not a measure dictated merely by consideration of convenience. Indeed, the accommodation which has to be provided at short notice for more than a hundred institutes, laboratories, museums, etc., forming the Academy is only obtainable in the already overcrowded Moscow mainly at the expense of other institutions, which are being moved elsewhere. New and spacious buildings are being erected at a 'shock speed', but mostly just planned, while many of the institutions are actually moving. In addition, living quarters have to be provided for the thousands of academic officials and their families, since all flats, rooms, etc. in Moscow are under the strictest State control. All these difficulties have resulted from the recent decree by which the Academy has been brought under the direct control of the Soviet of the People's Commissars. New statutes for the Academy are being prepared in order to replace "the old traditions of purely academic outlook" by work on problems connected with the "socialistic reconstruction" of the country. While the new order will possibly mean increased material support for some of the academic institutions, the decision as to whether or not a certain branch of abstract research deserves support will apparently be now in the hands of laymen officials. 